\title{
Pembangunan Geodatabase Ruang Terbuka Hijau Kota Bandung
}

\author{
FERI NALDI, INDRIANAWATI
}

\author{
Jurusan Teknik Geodesi \\ FTSP - Institut Teknologi Nasional, Bandung \\ Email: ferinaldi26@gmail.com
}

\begin{abstract}
ABSTRAK
Kota Bandung merupakan salah satu kota di Indonesia dengan tingkat pembangunan dan pertumbuhan penduduk yang cukup pesat, akibatnya di Kota Bandung terjadi penurunan daya dukung lingkungan hidup. Salah satu kegiatan yang dapat digunakan untuk memberikan informasi dalam menjaga keseimbangan ekologi Kota Bandung adalah dengan inventarisasi keberadaan dan ketersediaan Ruang Terbuka Hijau (RTH) melalui pembangunan geodatabase RTH. Penyediaan RTH pada suatu kawasan perkotaan telah diatur dalam Peraturan Menteri Pekerjaan Umum Nomor 05/PRT/M/2008, dimana proporsi RTH yang harus disediakan pada wilayah perkotaan adalah minimal sebesar $30 \%$ dari total luas wilayah kota. Pembangunan geodatabase RTH dilakukan dengan mengintegrasikan data spasial RTH dengan informasi tipologi RTH dan data foto/video RTH. Dari hasil pembangunan geodatabase dapat diketahui bahwa Kota Bandung mempunyai 22,59\% RTH publik $(3.802,5 \mathrm{Ha})$ dan 3,45\% RTH privat $(581,51 \mathrm{Ha}$ ) yang tersebar di seluruh Kota Bandung.
\end{abstract}

Kata kunci: SIG, Ruang Terbuka Hijau (RTH), Geodatabase

\begin{abstract}
Bandung is one of the cities in Indonesia with the level of development and population growth quite rapidly. Consequently, the carrying capacity of the environment in Bandung is decrease. One of the activities that can be used to provide information in maintaining the ecological balance of Bandung is the inventory of the existence and availability of green open space through the geodatabase development of green open space. Provision of green space in an urban area has been regulated in the Regulation of the Minister of Public Works No. 05/PRT/M/2008, where the proportion of green open space should be provided in urban areas is a minimum of $30 \%$ of the total area of the city. Geodatabase development of green open space is done by integrating spatial data of green open spaces with information of green open space typology and data of photos/videos of green open space. Results from the geodatabase development showed that Bandung has $22.59 \%$ public green open space (3802.5 ha) and 3.45\% private green open space (581.51 ha) which spread throughout the city of Bandung.
\end{abstract}

Keywords: GIS, Green Open Space, Geodatabase 


\section{PENDAHULUAN}

Berdasarkan Undang-Undang Nomor 26 Tahun 2007 tentang Penataan Ruang (Republik Indonesia, 2007), dijelaskan bahwa Ruang Terbuka Hijau (RTH) adalah area memanjang/jalur dan atau mengelompok, yang penggunaannya lebih bersifat terbuka, merupakan tempat tumbuh tanaman, baik tanaman yang tumbuh secara alamiah maupun yang sengaja ditanam. Keberadaan dan ketersediaan RTH pada kawasan perkotaan telah diatur dalam Peraturan Menteri Pekerjaan Umum Nomor 05/PRT/M/2008 Tentang Pedoman Penyediaan dan Pemanfaatan Ruang Terbuka Hijau di Kawasan Perkotaan, dimana proporsi RTH yang harus disediakan pada suatu wilayah perkotaan adalah minimal sebesar $30 \%$ dari total luas wilayah kota, yang terdiri dari $20 \%$ RTH publik dan $10 \%$ RTH privat (Kementerian Pekerjaan Umum, 2008). Proporsi 30\% merupakan ukuran minimal penyediaan RTH di kawasan perkotaan untuk menjamin keseimbangan ekologis kota. Namun pada kenyataannya, ketersediaan RTH di suatu kawasan perkotaan masih berada di bawah $30 \%$ dari total luas wilayahnya.

Pertumbuhan kegiatan ekonomi dan pembangunan yang terpusat pada suatu daerah perkotaan dapat menyebabkan terjadinya peningkatan jumlah penduduk. Jika dikaitkan dengan masalah luas lahan yang terbatas, maka akan berakibat terhadap menurunnya kualitas lingkungan. Meningkatnya pembangunan fisik kota yang berupa pengembangan kawasan pemukiman, fasilitas transportasi, perdagangan, industri, dan jasa lainnya dapat mengakibatkan bertambahnya pengalihan fungsi lahan dari ruang terbuka menjadi ruang terbangun yang selanjutnya berdampak pada berkurangnya Ruang Terbuka Hijau (Bahri dkk., 2012).

Kota Bandung merupakan salah satu kota di Indonesia dengan tingkat pembangunan dan pertumbuhan penduduk yang cukup pesat. Pesatnya pembangunan dan pertumbuhan penduduk di Kota Bandung ini telah berdampak pada penurunan daya dukung lingkungan hidup Kota Bandung. Daya dukung lingkungan hidup suatu kota akan dapat ditingkatkan kembali atau dapat dipertahankan dengan tetap menjaga keberadaan suatu aspek yang mempunyai peran besar terhadap kualitas lingkungan hidup, salah satu di antaranya yaitu keberadaan kawasan RTH. Dalam Materi Teknis Rencana Tata Ruang Wilayah (RTRW) Kota Bandung Tahun 2011-2031, disebutkan bahwa berdasarkan data tahun 2007, RTH Kota Bandung tersebar di enam Wilayah Pengembangan (WP) kota atau yang saat ini menjadi Sub Wilayah Kota (SWK) dengan luas yang beragam pada masing-masing wilayah. Wilayah yang memiliki RTH terluas adalah WP Ujungberung (saat ini terbagi menjadi SWK Ujungberung dan SWK Arcamanik), yaitu 351,76 Ha, sedangkan RTH terkecil terdapat pada WP Karees (saat ini SWK Karees), yaitu 26,77 Ha. Wilayah-wilayah lainnya memiliki proporsi luas antara proporsi kedua wilayah tersebut, yaitu WP Bojonegara (saat ini SWK Bojonegara) seluas 76,78 Ha; WP Cibeunying (saat ini SWK Cibeunying) seluas 57,57 Ha; WP Tegalega (saat ini SWK Tegallega) seluas 67,75 Ha; dan WP Gedebage (saat ini terbagi menjadi SWK Kordon dan SWK Gedebage) seluas 28,29 Ha (Bappeda Kota Bandung, 2013).

Karena pentingnya peran RTH dalam menjaga keseimbangan ekologi kota, maka diperlukan suatu kegiatan inventarisasi keberadaan dan ketersediaan RTH. Perkembangan teknologi informasi dan komunikasi saat ini telah menyediakan berbagai tools untuk mengelola data dan informasi. Salah satu teknologi yang dapat diimplementasikan untuk mengelola data dan informasi RTH adalah teknologi berbasis spasial atau yang dikenal dengan teknologi Sistem Informasi Geografis (SIG). Salah satu keunggulan dari teknologi SIG adalah memiliki kemampuan mengelola data spasial dalam suatu basis data spasial atau yang disebut dengan geodatabase. Geodatabase adalah sebuah basis data yang terintegrasi, menjadi 
pusat sumber data dan dapat diakses oleh berbagai aplikasi yang telah ada maupun yang akan dibangun untuk kebutuhan informasi dan analisis (Sumarno dan Indrianawati, 2011). Oleh karena itu, melalui penelitian ini dilakukan identifikasi keberadaan dan ketersediaan RTH Kota Bandung dengan membangun sebuah geodatabase RTH Kota Bandung.

\section{METODOLOGI}

Diagram alir metodologi penelitian yang dilakukan dapat dilihat pada Gambar 1.

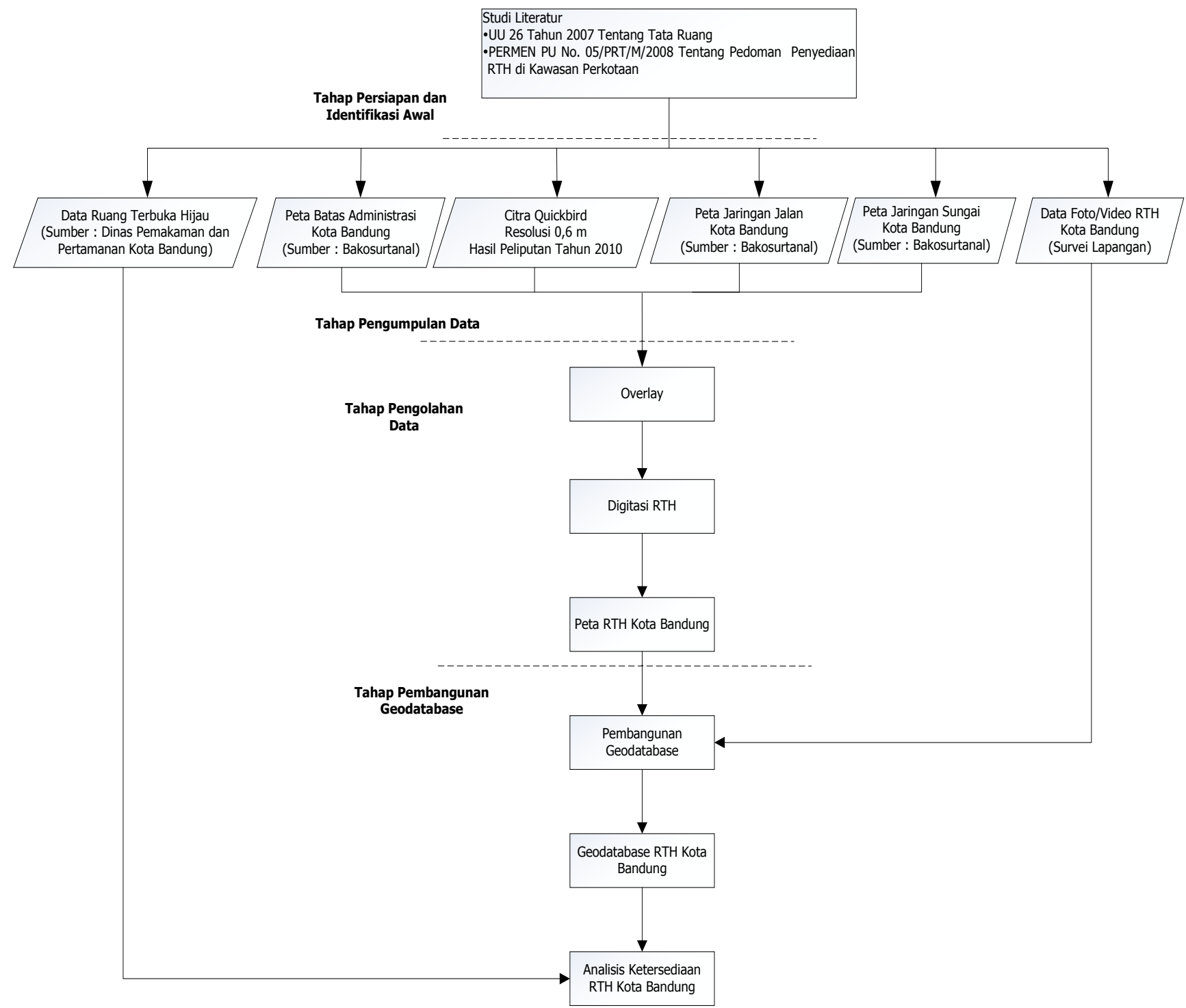

\section{Gambar 1 Diagram Alir Metodologi Penelitian}

Berikut adalah penjelasan dari diagram alir metodologi penelitian:

a) Persiapan dan Identifikasi Awal

Tahapan ini merupakan tahapan awal dalam penelitian, dimana dalam tahapan ini dilakukan identifikasi dan analisis terhadap ide pembangunan geodatabase RTH Kota Bandung. Dalam tahapan ini juga dilakukan studi literatur sehingga diketahui kebutuhan data dan informasi yang sesuai dengan sistem informasi yang akan dikembangkan. Studi literatur yang dilakukan meliputi pengkajian literatur yang berhubungan dengan pembangunan geodatabase dan peraturan perundang-undangan yang terkait dengan 
RTH, yaitu Undang-Undang Nomor 26 Tahun 2007 tentang Penataan Ruang dan Peraturan Menteri Pekerjaan Umum Nomor 05/PRT/M/2008 tentang Pedoman Penyediaan dan Pemanfaatan Ruang Terbuka Hijau di Kawasan Perkotaan.

b) Pengumpulan Data

Setelah dilakukan identifikasi dan analisis kebutuhan data, maka diperoleh jenis data apa saja yang dibutuhkan untuk membangun geodatabase RTH Kota Bandung. Adapun data yang dibutuhkan dalam pembangunan geodatabase RTH Kota Bandung yaitu berupa data Citra Quickbird, batas administrasi wilayah penelitian, data jaringan jalan, jaringan sungai, dan data survei lapangan berupa foto dan video RTH.

c) Pengolahan Data

Tahap pengolahan data secara garis besar terbagi dalam dua bagian, yaitu tahap pengolahan data spasial dan pengolahan data nonspasial. Pengolahan data spasial terdiri atas overlay dan digitasi jenis RTH. Adapun pengolahan data nonspasial terdiri atas melengkapi informasi RTH dan menghitung luas RTH.

d) Pembangunan Geodatabase

Pada tahap ini dilakukan perancangan dan pembangunan geodatabase RTH Kota Bandung dengan mengintegrasikan data spasial dan data nonspasial (atribut) sehingga dapat menyajikan informasi RTH Kota Bandung yang dapat menunjukkan informasi keberadaan dan ketersediaan RTH Kota Bandung. Seluruh pekerjaan pembangunan geodatabase RTH Kota Bandung dikerjakan menggunakan perangkat lunak ArcGIS.

\section{HASIL DAN ANALISIS}

\subsection{Luas RTH Kota Bandung}

Luas RTH Kota Bandung dihitung berdasarkan klasifikasi jenis RTH yang telah ditentukan mengacu kepada Peraturan Menteri Pekerjaan Umum Nomor 05/PRT/M/2008 Tentang Pedoman Penyediaan dan Pemanfaatan Ruang Terbuka Hijau di Kawasan Perkotaan. Berdasarkan peraturan tersebut, jenis RTH pada kawasan perkotaan terdiri dari RTH privat dan RTH publik. Luas total RTH di Kota Bandung adalah 4.384,01 Ha yang terdiri dari 581,51 Ha RTH privat dan 3.802,69 Ha RTH publik. Adapun rincian luas RTH Kota Bandung dapat dilihat pada Tabel 1.

Tabel 1 Luas RTH Kota Bandung

\begin{tabular}{|c|c|c|c|}
\hline No & Jenis RTH Publik & $\begin{array}{l}\text { Luas } \\
\text { (Ha) }\end{array}$ & $\begin{array}{c}\text { Proporsi Terhadap Luas } \\
\text { Wilayah Kota Bandung } \\
16.729,65 \mathrm{Ha} \\
(\%) \\
\end{array}$ \\
\hline \multirow[t]{5}{*}{ A } & RTH Privat & & \\
\hline & 1. Pekarangan Kantor & 381,95 & 2,28 \\
\hline & 2. Pekarangan Rumah & 199,51 & 1,19 \\
\hline & 3. Taman Atap & 0,04 & 0,00 \\
\hline & Total Luas RTH Privat & 581,51 & 3,48 \\
\hline \multirow[t]{14}{*}{ B } & RTH Publik & & \\
\hline & 1. Taman Kota & 144,71 & 0,87 \\
\hline & 2. Taman Kelurahan & 13,77 & 0,08 \\
\hline & 3. Sempadan Sungai & 21,59 & 0,13 \\
\hline & 4. Sempadan Rel Kereta Api & 1,41 & 0,01 \\
\hline & 5. Sempadan Jalan Tol & 30,2 & 0,18 \\
\hline & 6. Ruang di Bawah Jalan Layang & 0,34 & 0,00 \\
\hline & 7. Pulau Jalan dan Median Jalan & 30,24 & 0,18 \\
\hline & 8. Pemakaman & 137,03 & 0,82 \\
\hline & 9. Jalur Pejalan Kaki & 50,59 & 0,30 \\
\hline & 10. Hutan Kota & 0,00 & 0,00 \\
\hline & 11. Sabuk Hijau & $3.232,17$ & 19,32 \\
\hline & 12. Bandara & 140,64 & 0,84 \\
\hline & Total Luas RTH Publik & $3.802,69$ & 22,73 \\
\hline
\end{tabular}




\subsection{Geodatabase RTH Kota Bandung}

Hasil pembangunan geodatabase RTH Kota Bandung dapat dilihat pada Gambar 2. Geodatabase yang terbentuk merupakan hasil integrasi antara data spasial dan data nonspasial dari RTH Kota Bandung dengan menggunakan perangkat lunak ArcGIS.

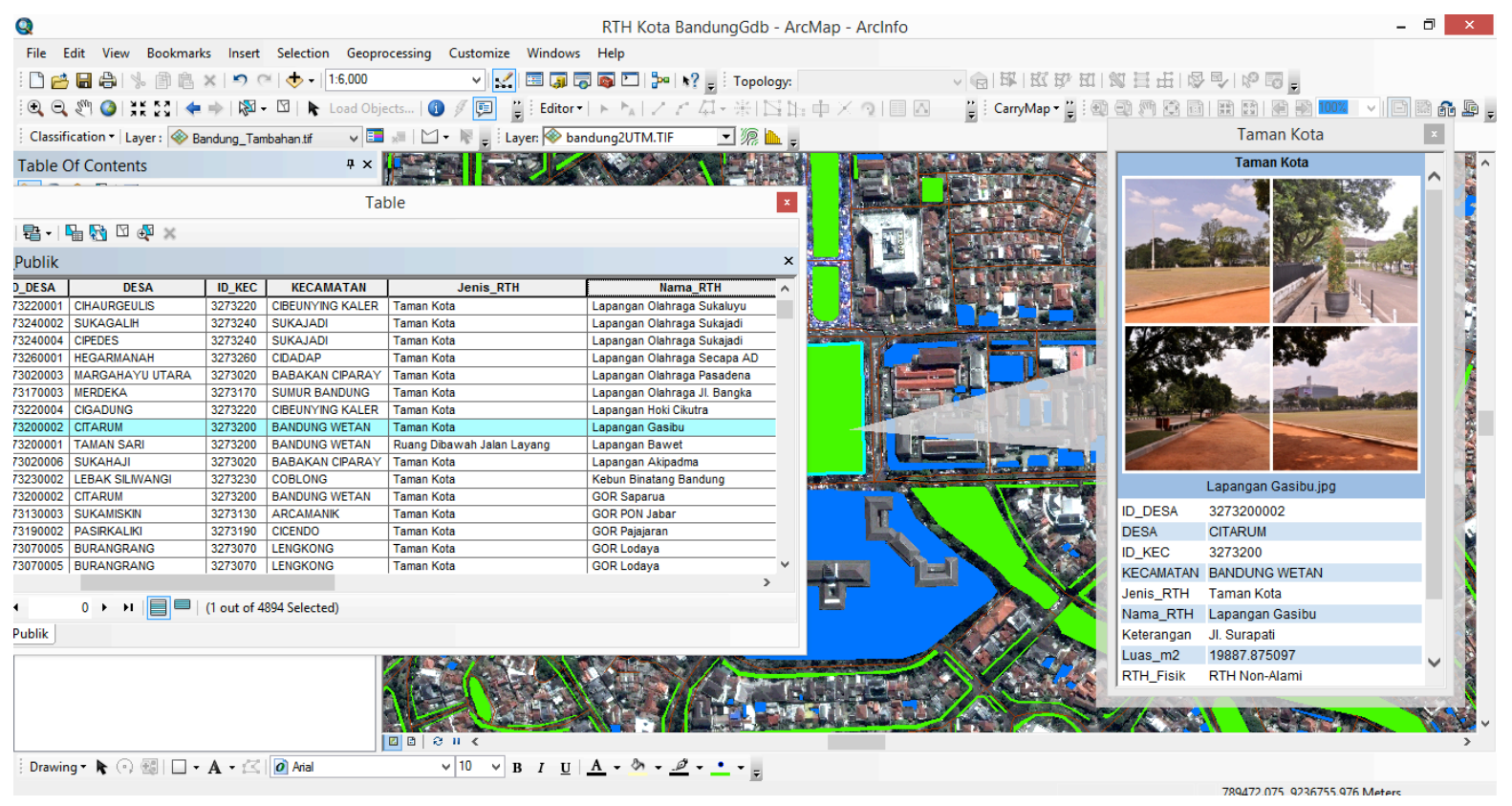

Gambar 2 Geodatabase RTH Kota Bandung

\subsection{Analisis}

a) Analisis Data

Data yang digunakan untuk memperoleh informasi spasial RTH Kota Bandung adalah data Citra Quickbird tahun 2010. Jika dilihat dari perkembangan Kota Bandung, dari tahun 2010 hingga saat ini, telah banyak perubahan penggunaan lahan yang terjadi di Kota Bandung. Selain ada lahan yang beralih fungsi dari ruang terbuka menjadi ruang terbangun, terdapat juga beberapa ruang terbuka yang kini menjadi ruang terbuka hijau. Dengan demikian untuk mendapatkan data spasial RTH dengan kondisi yang terbaru, maka dalam proses digitasi RTH digunakan data Citra Quickbird tahun 2010, yang didukung dengan data citra dari perangkat lunak Google Earth.

b) Analisis Pengolahan Data

Pada saat proses digitasi RTH, untuk mendapatkan batasan RTH, setiap RTH didigitasi dengan tingkat perbesaran (zooming) yang berbeda. Pengambilan batas RTH dengan metode tersebut menyebabkan ketelitian luas RTH yang satu dengan RTH yang lain menjadi berbeda-beda. Selain itu, pada saat proses digitasi RTH, jenis RTH jalur hijau jaringan listrik tegangan tinggi (SUTET), diidentifikasi ke dalam jenis RTH lain yaitu yang berupa RTH sabuk hijau. Hal ini disebabkan karena sebagian besar lokasi jalur SUTET berada di area persawahan (dapat dilihat pada Gambar 3), sehingga luas RTH jalur hijau jaringan listrik tegangan tinggi pada penelitian ini sudah termasuk ke dalam luas RTH sabuk hijau. 


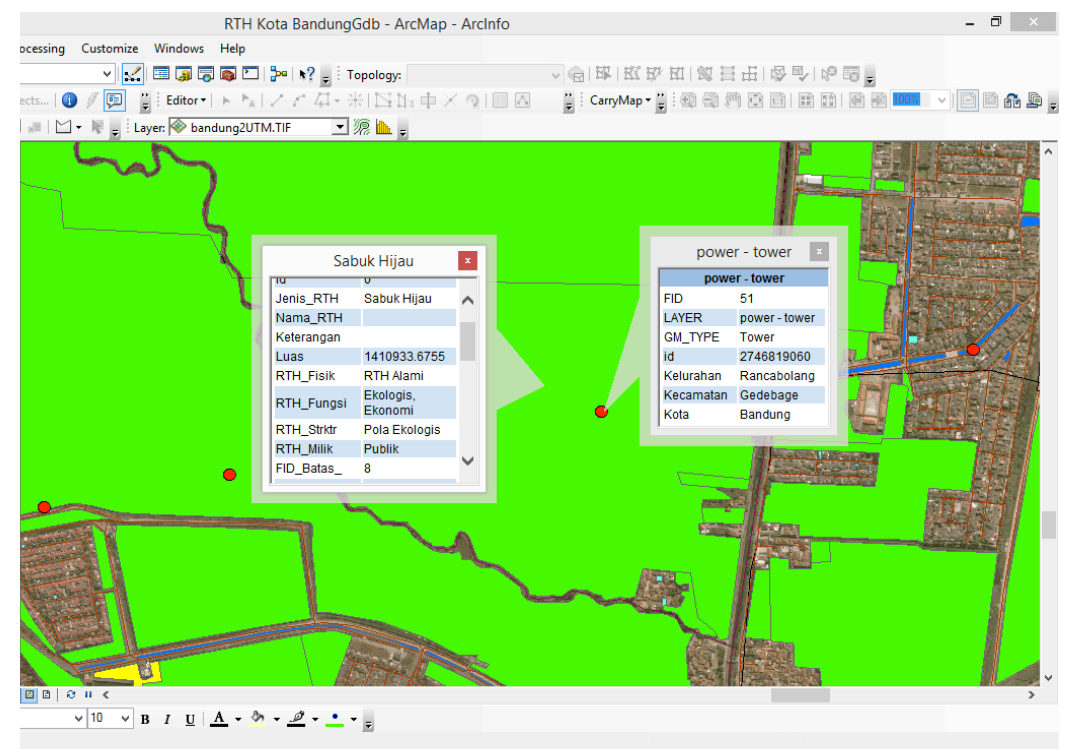

Gambar 3 Contoh Lokasi SUTET yang berada di Area Persawahan (Sabuk Hijau)

c) Analisis Pembangungan Geodatabase

Geodatabase yang terbentuk adalah jenis single user dengan tipe file geodatabase. Secara umum tipe single user dapat menyimpan data atribut hingga kapasitas 1 terabyte. Dalam penelitian yang dilakukan data atribut bersifat standar atau hanya memberikan gambaran umum mengenai keadaan RTH. Kelengkapan informasi geodatabase RTH Kota Bandung masih dapat ditingkatkan dengan menambahkan informasi yang lebih spesifik berkaitan dengan kondisi RTH.

d) Analisis Ketersediaan RTH Kota Bandung Menurut Peraturan Menteri Pekerjaan Umum No. 5 Tahun 2008, proporsi RTH yang harus disediakan pada suatu wilayah perkotaan adalah sebesar $30 \%$ dari total luas wilayah kota, yang terdiri atas 20\% RTH publik dan $10 \%$ RTH privat. Luas Kota Bandung berdasarkan Peraturan Daerah Kotamadya Daerah Tingkat II Bandung No. 10 Tahun 1989 adalah sebesar 16.729,65 Ha, sehingga idealnya Kota Bandung harus memiliki luas RTH sebesar 5.018,7 Ha. Dari hasil penelitian, luas RTH Kota Bandung adalah sebesar $4.384,01 \mathrm{Ha}$ atau 26,05\% dari luas wilayah kota. Luasan RTH Kota Bandung yang diperoleh dalam penelitian ini merupakan luasan RTH indikatif, dimana luas RTH diperoleh dari hasil digitasi citra dan tidak didukung dengan kegiatan pemetaan luas RTH di lapangan. Jika ditinjau dari kondisi ideal, ketersediaan RTH Kota Bandung tersebut mempunyai kekurangan sebesar 3,95\% dari proporsi RTH perkotaan yang seharusnya. Berikut perbandingan ketersediaan RTH Kota Bandung dengan kondisi ideal RTH untuk suatu kawasan perkotaan yang dapat dilihat pada Tabel 2.

Tabel 2 Perbandingan Ketersediaan RTH Kota Bandung dengan Kondisi Ideal RTH untuk Suatu Kawasan Perkotaan

\begin{tabular}{crrrrr}
\hline \multirow{2}{*}{ Jenis RTH } & \multicolumn{2}{c}{ Kondisi Ideal } & \multicolumn{2}{c}{ Hasil Penelitian } & \multirow{2}{*}{ Selisih (Ha) } \\
\cline { 2 - 5 } & Luas (Ha) & \% & Luas (Ha) & \multicolumn{1}{c}{$\%$} & \\
\hline \hline RTH publik & $3.345,8$ & 20 & $3.802,50$ & 22,59 & 456,70 \\
\hline RTH privat & $1.672,9$ & 10 & 581,51 & 3,45 & $1.091,39$ \\
\hline$\Sigma$ & $5.018,70$ & 30 & $4.384,01$ & 26,05 & 634,69 \\
\hline
\end{tabular}


Proporsi RTH publik Kota Bandung telah memenuhi syarat ketersediaan RTH untuk suatu kawasan perkotaan, yaitu $22,59 \%$ dari total wilayah kota. Namun, proporsi RTH privat Kota Bandung belum memenuhi syarat ketersediaan, seharusnya wilayah perkotaan memiliki $10 \%$ RTH privat, sedangkan Kota Bandung baru memiliki luas RTH privat dengan persentase sebesar 3,45\% dari total luas wilayah kota.

\section{KESIMPULAN}

Perancangan dan pembangunan geodatabase RTH Kota Bandung dilakukan berdasarkan Peraturan Menteri Pekerjaan Umum No. 05/PRT/M/2008 Tentang Pedoman Penyediaan dan Pemanfaatan Ruang Terbuka Hijau di Kawasan Perkotaan. Geodatabase RTH Kota Bandung dibangun dengan mengintegrasikan data spasial (berupa data batas administrasi, jaringan jalan, jaringan sungai, dan Citra Quickbird Kota Bandung) dengan data atribut (berupa tipologi RTH dan data foto/video RTH). Berdasarkan hasil pembangunan geodatabase RTH Kota Bandung, luas RTH di Kota Bandung adalah 4.384,01 Ha atau 26,05\% dari luas wilayah Kota Bandung, terdiri atas 3.802,50 Ha RTH publik dan 581,51 Ha RTH privat. Oleh karena itu, masih perlu adanya peningkatan jumlah RTH di Kota Bandung untuk memenuhi standar ketersediaan RTH untuk kawasan perkotaan yaitu sebesar $30 \%$ dari luas wilayah kota.

\section{DAFTAR PUSTAKA}

Bahri, S., Darusman, dan Ali, S.A. (2012). Kebutuhan Ruang Terbuka Hijau Kota Banda Aceh. Jurnal Manajemen Sumberdaya Lahan, Vol. 1 No.1, Juni 2012, hal 10-22. Fakultas Pertanian Unsyiah, Banda Aceh.

Bappeda Kota Bandung. (2013). Masterplan Ruang Terbuka Hijau Kota Bandung 2012-2032, Bandung.

Kementerian Pekerjaan Umum. (2008). Peraturan Menteri Pekerjaan Umum Nomor 05/PRT/M/2008 Tentang Pedoman Penyediaan dan Pemanfaatan Ruang Terbuka Hijau di Kawasan Perkotaan.

Republik Indonesia. (2007). Undang-Undang Nomor 26 Tahun 2007 Tentang Penataan Ruang. Sekretariat Negara Jakarta.

Sumarno dan Indrianawati. (2011). Pembangunan Geodatabase Kelautan dan Pulau-Pulau Kecil Terluar. Jurnal Rekayasa Itenas No. 1 Vol 15 Januari-Maret 2011 hal. 28. Institut Teknologi Nasional, Bandung. 